\title{
Tingkat pemangsaan Neoseiulus longispinosus Evans (Acari: Phytoseiidae) terhadap Tetranychus urticae Koch dan Tetranychus kanzawai Kishida (Acari: Tetranychidae) serta perilaku kanibalismenya
}

\author{
Predation capacities of Neoseiulus longispinosus Evans \\ (Acari: Phytoseiidae) against Tetranychus urticae Koch and \\ Tetranychus kanzawai Kishida (Acari: Tetranychidae) \\ and its cannibalistic behavior \\ Edwin Iswella ${ }^{*}$, Pudjianto ${ }^{2}$, Sugeng Santoso ${ }^{2}$ \\ ${ }^{1}$ Balai Besar Karantina Pertanian Tanjung Priok \\ Jalan Enggano No. 17, Jakarta Utara 14310 \\ ${ }^{2}$ Departemen Proteksi Tanaman, Fakultas Pertanian, Institut Pertanian Bogor \\ Jalan Kamper, Kampus IPB Dramaga, Bogor 16680
}

(diterima Juni 2015, disetujui Juni 2016)

\begin{abstract}
ABSTRAK
Tetranychus urticae Koch dan Tetranychus kanzawai Kishida merupakan hama penting pada beberapa jenis tanaman dan memiliki nilai ekonomi penting di Indonesia. Pengendalian tungau tersebut umumnya dengan menggunakan akarisida. Salah satu alternatif pengendalian adalah dengan menggunakan musuh alami tungau predator dari Famili Phytoseiidae. Sebagian besar Famili Phytoseiidae yang digunakan untuk pengendalian hayati tungau hama adalah phytoseiid eksotik yang tidak terdapat di Indonesia. Untuk itu, potensi tungau predator lokal perlu dikembangkan, salah satunya adalah Neoseiulus longispinosus Evans. Penelitian ini bertujuan untuk mengetahui tingkat pemangsaan $N$. longispinosus terhadap beberapa stadia $T$. urticae dan T. kanzawai serta pengaruh kerapatan predator terhadap perilaku kanibalismenya. $N$. longispinosus diberi mangsa telur dan imago betina $T$. urticae dan $T$. kanzawai untuk mengetahui tingkat pemangsaan. $N$. longispinosus juga diberi mangsa telur T. kanzawai dengan jumlah terbatas pada beberapa tingkat kerapatan predator untuk mengetahui perilaku kanibalismenya. Hasil penelitian menunjukkan rata-rata telur T. urticae dan $T$. kanzawai yang dimangsa deutonimfa dan imago betina $N$. longispinosus lebih tinggi dibandingkan dengan imago betina $T$. urticae dan T. kanzawai. Rata-rata telur T. urticae dan T. kanzawai yang dimangsa oleh imago betina $N$. longispinosus lebih tinggi dibandingkan dengan deutonimfanya. Jumlah telur yang diletakkan oleh imago betina $N$. longispinosus lebih tinggi pada saat diberi mangsa telur dibandingkan saat diberi mangsa imago betina. Deutonimfa dan imago betina $N$. longispinosus menunjukkan perilaku kanibalisme pada beberapa kerapatan predator dengan jumlah mangsa rendah.
\end{abstract}

Kata kunci: kanibalisme, Neoseiulus longispinosus, pemangsaan, Tetranychus urticae, T. kanzawai

\begin{abstract}
Tetranychus urticae Koch and Tetranychus kanzawai Kishida are important pests of various crops of economically importance in Indonesia. Acaricide are commonly used to control these mites. One of the alternative control methods is the use of phytoseiid predatory mites. Most of the phytoseiid
\end{abstract}


mites that are used as biological control agents are exotic mites. For that reasons, it is necessary to study indegenous predatory mites that has the potential to be developed as biological control, such as Neoseiulus longispinosus Evans. The objective of this study was to determine the predation capacities of $N$. longispinosus on two red spider mites of T. urticae and T. kanzawai and the effect of predator densities to predator cannibalistic behavior. $N$. longispinosus were supplied with eggs and adults of T. urticae and T. kanzawai to determine the predation capacities. $N$. longispinosus were also supplied low number of T. kanzawai eggs as the prey at several predator densities to see its cannibalistic behavior. The results showed that the number of eggs of T. urticae dan T. kanzawai consumed by deutonymphs and adult females of $N$. longispinosus was higher than the adult female of T. urticae dan T. kanzawai. The number of eggs of T. urticae dan T. kanzawai consumed by adult female $N$. longispinosus was higher than by the deutonymphs. The number of eggs laid by adult females of $N$. longispinosus when feed on eggs of T. urticae and T. kanzawai was higher than those feed on adult female. Deutonymph and female adult stage of $N$. longispinosus showed cannibalistic behavior at several predator densities in low number of prey.

Key words: cannibalistic, Neoseiulus longispinosus, predation, Tetranychus urticae, T. kanzawai

\section{PENDAHULUAN}

Tungau laba-laba merupakan tungau hama yang sangat penting dan merusak pada beberapa jenis tanaman di Indonesia. Tungau ini termasuk dalam Famili Tetranychidae. Tetranychus urticae Koch dan Tetranychus kanzawai Kishida merupakan beberapa tungau hama penting dari Famili Tetranychidae yang sebagian besar bersifat polifag (Zhang 2003). Pengendalian tungau tersebut umumnya dilakukan dengan menggunakan akarisida. Salah satu alternatif pengendalian yang ramah lingkungan adalah dengan menggunakan musuh alami tungau predator dari Famili Phytoseiidae. Tungau predator Famili Phytoseiidae telah diketahui menjadi musuh alami yang sangat penting bagi tungau laba-laba (Gotoh et al. 2004). Tungau predator tersebut umumnya memangsa tungau hama, serangga kecil, nematoda, cendawan, dan dapat juga memakan nektar serta eksudat tanaman (Zhang 2003).

Beberapa spesies yang banyak dimanfaatkan untuk pengendalian tungau hama di rumah kaca adalah genus Neoseiulus dan Phytoseiulus yang termasuk dalam Subfamili Amblyseiinae dan Phytoseiinae(Zhang 2003). Phytoseiulus persimilis Athias-Henriot dan Amblyseius californicus (McGregor) merupakan contoh spesies yang telah diproduksi secara komersial (Cakmak et al. 2005). Sebagian besar Famili Phytoseiidae yang digunakan untuk pengendalian hayati tungau hama di Indonesia adalah termasuk phytoseiid eksotik. Untuk itu perlu dikembangkan potensi tungau predator yang terdapat di Indonesia, salah satunya adalah Neoseiulus longispinosus Evans.
N. longispinosus termasuk dalam Famili Phytoseiidae, Ordo Mesostigmata (Zhang 2003). $N$. longispinosus berhubungan dekat dengan Neoseiulus womersleyi (Schicha) secara biosistematika (Zhang 2003; Gerson et al. 2003). Daerah sebar $N$. longispinosus meliputi Rusia, China, Jepang, Thailand, Australia, Hawai (Zhang 2003; Kongchuensin et al. 2005), India, Taiwan, Filipina, Malaysia, Indonesia, dan Selandia Baru (Gerson et al. (2003). N. longispinosus pertama kali dilaporkan dan ditemukan berasosiasi dengan Tetranychus bimaculatus Harvey pada tanaman ubi kayu di Indonesia (Evans 1952). N. longispinosus banyak ditemukan berasosiasi dengan tungau hama Famili Tetranychidae pada tanaman stroberi, jeruk, dan ubi kayu (Puspitarini 2005; Rachman 2011). N. longispinosus termasuk predator tipe 2 , yang memiliki preferensi mangsa pada tungau Tetranychidae dan juga dapat memakan polen (Gerson et al. 2003; Zhang 2003). Di beberapa negara, Neoseiulus (Amblyseius) spp. telah digunakan untuk pengendalian hayati T. urticae pada stroberi dan tanaman budi daya lainnya (Cross et al. 2001). Zhang et al. (1999) melaporkan bahwa $N$. longispinosus berasosiasi dan memangsa tungau Schizotetranychus nanjingensis Ma \& Yuan (Acari: Tetranychidae), yang menginfestasi bambu di China dan efektif dalam mengendalikan tungau hama tersebut pada suhu tinggi $\left(30-35^{\circ} \mathrm{C}\right)$.

Informasi mengenai potensi $N$. longispinosus di Indonesia masih sangat terbatas dan belum dimanfaatkan secara maksimal untuk pengendalian hayati. Untuk itu, diperlukan adanya penelitian mengenai potensi tungau predator tersebut. Penelitian ini bertujuan untuk mengetahui tingkat 
pemangsaan $N$. longispinosus terhadap beberapa stadia T. urticae dan T. kanzawai serta pengaruh kerapatan predator terhadap perilaku kanibalisme predator.

\section{BAHAN DAN METODE}

\section{Pemeliharaan N. longispinosus, T. urticae, dan} T. kanzawai

Pemeliharaan tungau predator dan tungau hama dilaksanakan di Laboratorium Bionomi dan Ekologi Serangga, Departemen Proteksi Tanaman (DPT), Fakultas Pertanian (Faperta), Institut Pertanian Bogor (IPB). Tungau T. urticae diambil dari pertanaman stroberi di daerah Cipanas, sedangkan T. kanzawai diambil dari pertanaman ubi kayu di Dramaga Bogor. Tungau tersebut dipelihara pada arena berupa cawan petri $(\varnothing=6 \mathrm{~cm})$, yang di dalamnya secara berurutan diletakkan busa $(\varnothing=5,5 \mathrm{~cm})$, kapas $(5 \mathrm{~cm} \mathrm{x} 4 \mathrm{~cm})$, dan daun ubi kayu. Busa dan kapas dijenuhi dengan air untuk menjaga kesegaran daun ubi kayu dan mencegah tungau keluar dari arena percobaan (Rachman 2011). Tungau predator $N$. longispinosus dipelihara dan diperbanyak pada arena percobaan yang berisi tungau T. urticae dan atau T. kanzawai. Setiap tiga hari tungau predator ini dipindahkan ke arena pemeliharaan yang baru agar berkembang biak. Pemeliharaan T. kanzawai juga dilakukan pada tanaman ubi kayu di dalam pot plastik untuk menjaga persediaan mangsa bagi pemeliharaan $N$. longispinosus.

\section{Tingkat pemangsaan $N$. longispinosus terhadap stadia T. urticae dan T. kanzawai}

Pengujian tingkat pemangsaan $N$. longispinosus terhadap stadia $T$. urticae dan T. kanzawai dilaksanakan di Laboratorium Bionomi dan Ekologi Serangga, DPT, Faperta, IPB. Predator yang diuji adalah stadia deutonimfa dan imago betina $N$. longispinosus dengan mangsa telur dan imago betina T. urticae dan T. kanzawai. Arena percobaan berupa cawan petri $(\varnothing=6 \mathrm{~cm})$, yang di dalamnya secara berurutan diletakkan busa $(\varnothing=$ $5,5 \mathrm{~cm})$, kapas $(5 \mathrm{~cm} \times 4 \mathrm{~cm})$, dan daun ubi kayu berukuran $2 \mathrm{~cm} \times 2 \mathrm{~cm}$. Pada arena percobaan diletakkan masing-masing 30 butir telur atau 10 individu imago betina T. urticae dan T. kanzawai. $\mathrm{Ke}$ dalam arena percobaan dimasukkan masing- masing 1 individu deutonimfa atau imago betina $N$. longispinosus yang telah dipuasakan selama 6 jam. Predator dibiarkan selama 24 jam di dalam arena percobaan. Jumlah telur dan imago betina $T$. urticae dan T. kanzawai yang dimangsa kemudian dihitung. Jumlah telur yang diletakkan oleh imago betina $N$. longispinosus juga dihitung untuk mengetahui tingkat oviposisi $N$. longispinosus saat diberi mangsa dengan stadia berbeda.

Pengujian tingkat pemangsaan menggunakan rancangan acak lengkap (RAL) faktorial dengan 2 faktor. Faktor pertama, yaitu stadia tungau predator $N$. longispinosus yang terdiri atas 2 taraf, yaitu deutonimfa dan imago betina. Faktor kedua adalah stadia mangsa yang terdiri atas 4 taraf, yaitu telur $T$. urticae, imago betina $T$. urticae, telur T. kanzawai, dan imago betina T. kanzawai. Terdapat 8 kombinasi perlakuan. Pengujian diulang sebanyak 5 kali.

\section{Pengaruh kerapatan predator terhadap perilaku kanibalisme}

Pengujian kerapatan predator terhadap perilaku kanibalisme dilaksanakan di Laboratorium Bionomi dan Ekologi Serangga, DPT, Faperta, IPB. Predator yang diuji adalah stadia deutonimfa dan imago betina $N$. longispinosus. Percobaan ini dilakukan pada arena percobaan yang sama dengan pengujian tingkat pemangsaan. Stadia predator yang digunakan adalah imago betina dan deutonimfa $N$. longispinosus. Ke dalam arena percobaan terpisah yang berisi 10 telur T. kanzawai dimasukkan deutonimfa, imago betina atau campuran $(1: 1)$ antara deutonimfa dan imago betina tungau predator yang telah dipuasakan selama 6 jam dengan kepadatan 2, 4, 6 , dan 8 individu predator. Pengamatan dilakukan 24 jam setelah perlakuan dengan mencatat jumlah mangsa dan predator yang hilang atau rusak karena dimangsa predator lain. Jumlah telur $N$. longispinosus yang diletakkan dihitung setelah 24 jam untuk mengetahui tingkat oviposisi predator pada kondisi jumlah mangsa terbatas. Pengujian menggunakan RAL terdiri atas 4 perlakuan, yaitu kerapatan 2, 4, 6, dan 8 individu predator. Parameter yang diamati, yaitu jumlah predator yang dimangsa predator lainnya pada stadia deutonimfa, imago betina, dan campuran (deutonimfa dan imago betina). Pengujian diulang sebanyak 5 kali. 


\section{Analisis data}

Data hasil pengujian dianalisis menggunakan ANOVA pada tingkat kepercayaan $95 \%$, apabila hasil ANOVA berbeda nyata dilanjutkan dengan Uji Tukey pada taraf nyata 5\%. Data diolah dengan program Minitab 16.

\section{HASIL}

\section{Tingkat pemangsaan $N$. longispinosus terhadap} stadia T. urticae dan T. kanzawai

Interaksi antara stadia predator dan stadia mangsa memberikan pengaruh nyata $\left(\mathrm{F}_{2,48}=\right.$ $10,21 ; \mathrm{P}=0,003)$ terhadap tingkat pemangsaan $N$. longispinosus.

Rata-rata telur T. urticae dan T. kanzawai yang dimangsa deutonimfa dan imago betina $N$. longispinosus lebih tinggi dibandingkan dengan imago betina T. urticae dan T. kanzawai (Tabel 1). Rata-rata telur T. urticae dan T. kanzawai yang dimangsa oleh imago betina $N$. longispinosus lebih tinggi dibandingkan dengan deutonimfa $N$. longispinosus, tetapi rata-rata imago betina $T$. urticae dan T. kanzawai yang dimangsa imago betina $N$. longispinosus tidak berbeda dengan deutonimfa $N$. longispinosus (Tabel 1).

Rata-rata telur yang diletakkan oleh imago betina predator $N$. longispinosus pada saat diberikan mangsa telur T. urticae dan T. kanzawai (2 dan 1,8 butir) lebih tinggi $\left(\mathrm{F}_{2,19}=22,25 ; \mathrm{P}=\right.$ $0,000)$ dibandingkan saat diberikan mangsa imago betina T. urticae dan T. kanzawai $(0,9$ dan 0,7 butir) (Gambar 1).

\section{Pengaruh kerapatan predator terhadap peri- laku kanibalisme}

Tingkat kerapatan predator memberikan pengaruh nyata $\left(\mathrm{F}_{2,19}=20,77 ; \mathrm{P}=0,000\right)$ terhadap terjadinya perilaku kanibalisme $N$. longispinosus pada stadia yang sama (deutonimfa atau imago betina) dan stadia campuran (deutonimfa dan imago betina). Jumlah deutonimfa yang dimangsa oleh deutonimfa lainnya pada kerapatan 2 predator berbeda dengan kerapatan 6 predator, tetapi tidak berbeda dengan kerapatan 4 dan 8 (Tabel 2). Jumlah imago betina yang dimangsa imago betina lainnya pada kerapatan 2 berbeda dengan kerapatan 8

Tabel 1. Rata-rata pemangsaan Neoseiulus longispinosus terhadap telur dan imago betina Tetranychus urticae dan T. kanzawai $( \pm \mathrm{SD})^{\mathrm{a}}$

\begin{tabular}{llrr}
\hline \multirow{2}{*}{ Spesies mangsa } & \multirow{2}{*}{ Stadia mangsa } & \multicolumn{2}{c}{ Stadia predator (N. longispinosus) } \\
\cline { 3 - 4 } & & Deutonimfa & Imago betina \\
\hline Tetranychus urticae & Telur & $9,00 \pm 2,03 \mathrm{~b}$ & $14,15 \pm 1,87 \mathrm{a}$ \\
& Imago betina & $1,05 \pm 0,32 \mathrm{c}$ & $1,95 \pm 0,32 \mathrm{c}$ \\
Tetranychus kanzawai & Telur & $9,15 \pm 1,14 \mathrm{~b}$ & $15,15 \pm 1,20 \mathrm{a}$ \\
& Imago betina & $1,05 \pm 0,41 \mathrm{c}$ & $2,15 \pm 0,57 \mathrm{c}$ \\
\hline
\end{tabular}

${ }^{a}$ Rataan yang diikuti oleh huruf yang sama menunjukan tidak berbeda nyata pada uji Tukey, $\alpha=0,05$

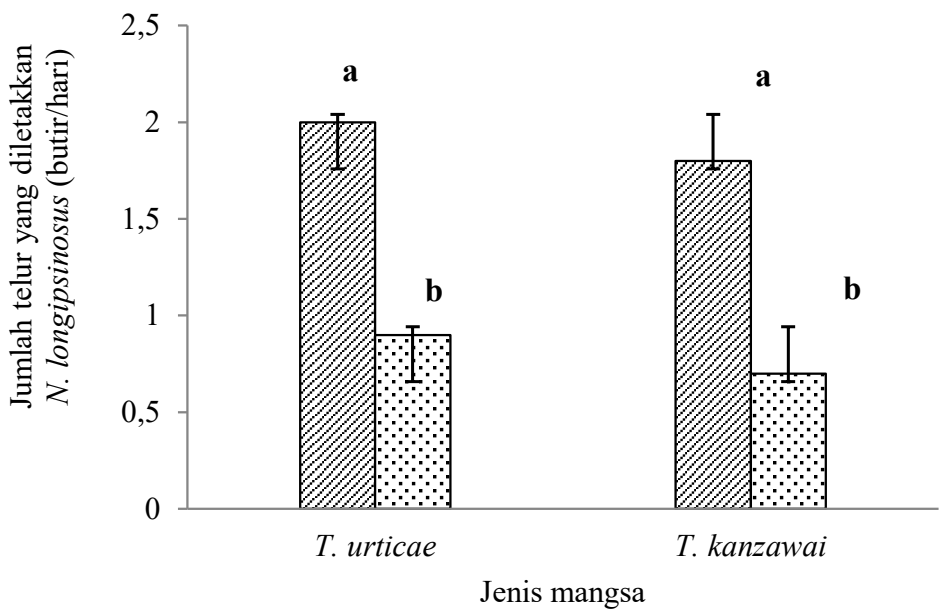

Gambar 1. Jumlah telur (rataan $\pm \mathrm{SD}$ ) yang diletakkan oleh imago betina Neoseiulus longispinosus pada uji tingkat pemangsaan predator $\left(\mathrm{F}_{2,19}=22,25 ; \mathrm{P}=0,000\right)$. ø': telur; $₫$ : imago betina. 
predator, tetapi tidak berbeda dengan kerapatan 4 dan 6 predator (Tabel 2). Jumlah deutonimfa dan imago betina pada stadia campuran yang dimangsa predator lainnya pada kerapatan 2 dan 4 berbeda dengan kerapatan 6 dan 8 (Tabel 2). Imago betina $N$. longispinosus masih dapat menghasilkan telur walaupun dalam kondisi jumlah mangsa yang rendah. Jumlah telur yang diletakkan imago betina $N$. longispinosus semakin meningkat dengan meningkatnya kerapatan predator (Gambar 2).

\section{PEMBAHASAN}

Tingkat pemangsaan deutonimfa dan imago betina $N$. longispinosus terhadap telur T. urticae dan T. kanzawai lebih tinggi dibandingkan dengan imago betina T. urticae dan T. kanzawai. Hal ini menunjukkan bahwa deutonimfa dan imago betina $N$. longispinosus lebih memilih telur sebagai mangsanya. Predator lebih mudah menemukan dan menangani mangsa berupa telur karena telur tidak bergerak dan tidak memiliki kemampuan untuk melakukan perlawanan. Hal ini sesuai dengan hasil penelitian Song et al. (2016) yang menyatakan bahwa $N$. longispinosus lebih banyak mengkonsumsi telur $T$. urticae dan T. kanzawai dibanding larva dan nimfa $T$. urticae dan $T$. kanzawai. Hal yang sama juga dinyatakan oleh Puspitarini (2005) yang menyatakan bahwa imago betina dan deutonimfa Amblyseius longispinosus (Evans) lebih memilih telur Panonychus citri McGregor (Acari: Tetranychidae) sebagai mangsanya. Menurut McMurty \& Rodriguez (1987), tungau phytoseiid lebih banyak mengkonsumsi telur dibanding larva, nimfa atau imago Tetranychidae. Stadia dan jenis mangsa diduga mempengaruhi perilaku pemangsaan predator terhadap mangsa.

Tingkat pemangsaan juga ditentukan oleh kandungan nutrisi mangsa dan suhu. Mangsa yang berbeda menyediakan kandungan nutrisi yang berbeda pula (Hoy 2011). Tingkat pemangsaaan A. longispinosus terhadap Aponycus corpuzae Rimando (Acari: Tetranychidae) dan $S$. nanjingensis (Acari: Tetranychidae) ditentukan oleh faktor suhu dimana tingkat pemangsaan akan meningkat dengan meningkatnya suhu sampai

Tabel 2. Rata-rata jumlah predator yang dimangsa predator lainnya pada stadia sama dan stadia campuran pada beberapa tingkat kerapatan predator

\begin{tabular}{lllc}
\hline \multirow{2}{*}{ Kerapatan predator } & \multicolumn{3}{c}{ Jumlah predator yang dimangsa (rataan \pm SD) pada stadia } \\
\cline { 2 - 4 } & Deutonimfa & Imago betina & Deutonimfa dan Imago betina $^{\mathrm{b}}$ \\
\hline 2 & $0,30 \pm 0,27 \mathrm{bc}$ & $0,00 \pm 0,00 \mathrm{c}$ & $0,10 \pm 0,22 \mathrm{~b}$ \\
4 & $0,50 \pm 0,35 \mathrm{abc}$ & $0,30 \pm 0,27 \mathrm{bc}$ & $0,60 \pm 0,41 \mathrm{~b}$ \\
6 & $1,20 \pm 0,27 \mathrm{a}$ & $0,70 \pm 0,75 \mathrm{abc}$ & $1,70 \pm 0,44 \mathrm{a}$ \\
8 & $1,00 \pm 0,50 \mathrm{ab}$ & $1,10 \pm 0,41 \mathrm{ab}$ & $1,70 \pm 0,44 \mathrm{a}$ \\
\hline
\end{tabular}

${ }^{a}$ Rata-rata pada kolom yang sama yang diikuti oleh huruf yang sama tidak berbeda nyata pada uji Tukey $\alpha=0.05$

${ }^{\mathrm{b}}$ Perbandingan jumlah antar fase campuran deutonimfa dan imago betina $1: 1$.

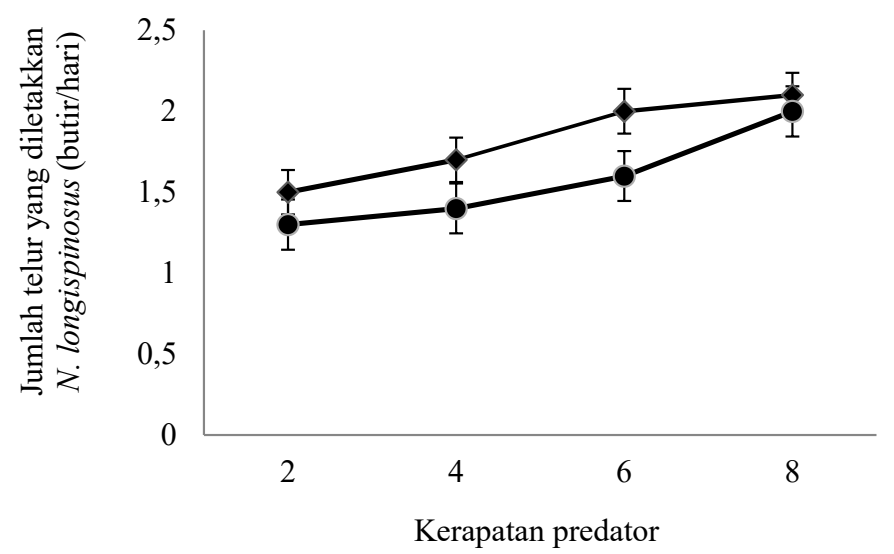

Gambar 2. Jumlah telur (rataan \pm SE) yang diletakkan oleh imago betina Neoseiulus longispinosus pada uji pengaruh kerapatan predator terhadap perilaku kanibalisme pada stadia yang sama dan stadia

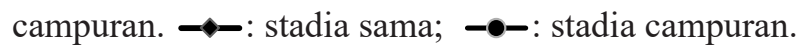


pada batas suhu tertentu (Zhang et al. 1999). Hasil penelitian Zhang et al. (1999) menunjukkan bahwa $A$. longispinosus efektif mengendalikan $S$. nanjingensis pada suhu $30-35{ }^{\circ} \mathrm{C}$, tetapi efektifitasnya menurun pada suhu $10-15{ }^{\circ} \mathrm{C}$. Tingkat pemangsaan $N$. longispinosus diduga lebih efektif pada suhu tinggi dibandingkan pada suhu rendah. Pada pengujian ini suhu ratarata laboratorium adalah $29{ }^{\circ} \mathrm{C}$ sehingga dapat dianggap sebagai suhu yang cukup optimal untuk memangsa T. urticae dan T. kanzawai.

Tingkat pemangsaan predator juga terkait dengan efisiensi pencarian mangsa oleh predator. Menurut Huffaker et al. (1971), predator melakukan pencarian mangsa secara acak sampai terjadi kontak dengan mangsa. Selain itu, pencarian mangsa oleh predator juga dipengaruhi oleh permukaan daun. Hasil penelitian Krips et al. (1999), menunjukkan bahwa efisiensi pencarian P. persimilis pada daun Gerbera spp, dipengaruhi oleh kepadatan trikoma pada permukaan daun. Dalam pengujian ini, digunakan daun ubi kayu sebagai arena percobaan yang tidak/sedikit memiliki trikoma daun. Luas arena percobaan dan tingkat kelaparan predator, diduga juga merupakan faktor yang mempengaruhi efisiensi pencarian mangsa oleh predator. McMurty \& Rodriguez (1987) menyatakan bahwa tingkat kelaparan mempengaruhi rasio pertemuan dan penangkapan mangsa oleh tungau predator.

Tingkat pemangsaan imago betina $N$. longispinosus terhadap telur T. urticae dan $T$. kanzawai lebih tinggi dibandingkan dengan deutonimfa $N$. longispinosus. Hal ini menunjukkan bahwa imago betina N. longispinosus memiliki kemampuan memangsa yang lebih tinggi terhadap stadia telur dibandingkan dengan deutonimfa predator. Halini diduga berkaitan dengan kebutuhan energi imago betina yang lebih besar dibandingkan dengan deutonimfa $N$. longispinosus, khususnya ketika imago betina pada masa praoviposisi dan oviposisi. Selain itu, stadia dan jenis mangsa serta suhu diduga mempengaruhi perilaku pemangsaan predator terhadap mangsa. Hasil penelitian Song et al. (2016) menyatakan bahwa imago betina $N$. longispinosus dapat memangsa telur T. urticae sebanyak 18,43 butir dan telur T. kanzawai sebanyak 24,15 butir pada suhu $25^{\circ} \mathrm{C}$.

Tingkat pemangsaan imago betina $N$. longispinosus terhadap imago betina $T$. urticae 170 dan T. kanzawai tidak berbeda dengan deutonimfa $N$. longispinosus. Hal ini diduga disebabkan oleh kemampuan imago betina mangsa untuk bergerak menghindari predator dan melakukan perlawanan. Selain itu juga, disebabkan oleh ukuran imago betina mangsa yang besar. Semakin besar ukuran tubuh mangsa maka penanganannya membutuhkan waktu yang lama dan energi yang besar. Hasil penelitian Rahman et al. (2013) menyatakan bahwa imago betina $N$. longispinosus lebih banyak memangsa larva dan nimfa dibanding imago Olygonychus coffeae Nietner.

Jumlah telur yang diletakkan oleh imago betina $N$. longispinosus lebih tinggi pada saat diberi mangsa telur T. urticae dan T. kanzawai dibandingkan dengan saat diberi mangsa imago betina T. urticae dan T. kanzawai (Gambar 1). Hal ini diduga berkaitan dengan kandungan nutrisi stadia mangsa. Stadia telur diketahui memiliki kandungan protein yang tinggi (Sabelis 1985), yang sangat dibutuhkan untuk pembentukan telur. Hasil penelitian Oliviera et al. (2007) menunjukkan rata-rata oviposisi Phytoseiulus macropilis Banks tertinggi saat diberikan mangsa telur dan kombinasi telur dan imago T. urticae. Umumnya imago betina phytoseiid dapat menghasilkan 2-4 telur perhari dengan total 20-50 telur per imago betina selama hidupnya (Hoy 2011). Faktor lain yang mempengaruhi tingkat oviposisi adalah suhu. Rata-rata telur yang diletakkan $N$. longipsinosus lebih tinggi pada temperatur $30{ }^{\circ} \mathrm{C}$ dibanding pada temperatur $20-25{ }^{\circ} \mathrm{C}$ saat diberikan mangsa O. coffeae (Rahman et al. 2013). Jenis mangsa dan tingkat pemangsaan predator terhadap telur dan imago betina (Tabel 1) sangat berkaitan dengan rata-rata telur yang diletakkan oleh imago betina predator (Gambar 1). Sebagaimana yang diungkapkan oleh Sabelis (1985) bahwa oviposisi sangat berhubungan dengan tingkat pemangsaan karena tungau predator phytoseiid sebagian besar mengalokasikan sebagian besar nutrisi untuk pembentukan telur. Imago betina phytoseiid membutuhkan 20-25 butir telur tungau laba-laba per hari untuk mendepositkan seluruh bagian telur yang lengkap, sementara imago jantan dan pradewasa membutuhkan jumlah yang lebih sedikit (Hoy 2011).

Tingkat kerapatan predator memberikan pengaruh terhadap terjadinya kanibalisme predator baik pada stadia yang sama dan stadia campuran 
saat diberi mangsa dengan jumlah yang sama (Tabel 2). Hal ini diduga karena pada kerapatan tertentu dengan jumlah mangsa sedikit, predator akan berusaha untuk bertahan hidup dengan memangsa predator lainnya. Jadi, perilaku kanibalisme pada pengujian ini sangat ditentukan oleh stadia dan jumlah mangsa serta stadia dan jumlah predator. Umumnya kanibalisme terjadi pada predator stadia akhir yang memangsa predator yang stadianya lebih awal (Agarwala \& Dixon 1992). Berdasarkan pengujian ini, perilaku kanibalisme juga dapat terjadi pada stadia yang sama yang memangsa sesamanya. Hoy (2011) menyatakan bahwa kanibalisme pada spesies sendiri dan intraguild predation (IGP) pada spesies phytoseiidae lainnya dapat menjadi keuntungan jika dapat membuat predator bertahan pada saat kondisi populasi mangsa yang rendah.

Imago betina $N$. longispinosus masih dapat menghasilkan telur walaupun dalam kondisi mangsa yang rendah. Hal ini diduga karena imago betina $N$. longispinosus masih mendapat nutrisi dari pemangsaan mangsa dan pemangsaan sesama predator (kanibalisme) pada arena percobaan. Keadaan minimnya sumber daya makanan menyebabkan imago betina predator lebih mengalokasikan energi untuk metabolisme dibandingkan untuk pembentukan telur. Hasil penelitinan Momen (2010) menyatakan bahwa nutrisi yang didapatkan oleh Neoseiulus barkeri Hughes (Acari: Phtyoseiidae) dari proses kanibalisme (larva atau nimfa) membuat predator dapat bereproduksi dan bertahan untuk beberapa waktu. Hal yang sama juga diungkapkan oleh Meszaros et al. (2007) bahwa Typhlodromus exhilaratus Ragusa dan Typhlodromus phialatus Athias-Henriot dapat menghasilkan telur pada uji kanibalisme dan pemangsaan jenis phytoseiid lainnya. Menurut Hoy (2011), imago betina tungau predator dapat menyimpan deposit sperma. Selain itu, diduga telah terjadi proses kopulasi pada saat di arena pemeliharaan.

\section{KESIMPULAN}

Tingkat pemangsaan deutonimfa dan imago betina $N$. longispinosus terhadap telur T. urticae dan T. kanzawai lebih tinggi dibandingkan dengan imago betinanya. Tingkat pemangsaan imago betina $N$. longispinosus terhadap telur $T$. urticae T. kanzawai lebih tinggi dibandingkan dengan deutonimfa $N$. longispinosus. Jumlah telur yang diletakkan oleh imago betina $N$. longispinosus lebih tinggi pada saat diberi mangsa telur dibanding saat diberi mangsa imago betina. Deutonimfa dan imago betina $N$. longispinosus menunjukkan perilaku kanibalisme pada beberapa kerapatan predator dengan jumlah mangsa rendah.

\section{UCAPAN TERIMA KASIH}

Ucapan terima kasih disampaikan kepada Badan Karantina Pertanian atas bantuan beasiswa studi di Sekolah Pascasarjana Institut Pertanian Bogor serta Laboratorium Bionomi dan Ekologi Serangga, Departemen Proteksi Tanaman, Fakultas Pertanian, IPB yang telah mengijinkan penggunaan tempat penelitian.

\section{DAFTAR PUSTAKA}

Agarwala BK, Dixon AFG. 1992. Laboratory study of cannibalism and interspecific predation in ladybird. Ecological Entomology 17:303-309. doi: https://doi.org/10.1111/j.1365-2311.1992. tb01062.x.

Cakmak I, Baspinar H, Madanlar N. 2005. Control of carmine spider mite Tetranychus cinnabarinus Boisduval by the predatory mite Phytoseiulus persimilis (Athias-Henriot) in protected strawberry in Aydin, Turkey. Turkish Journal of Agriculture and Forestry 29:259-265. doi: https ;//doi.org/ 05.29.4/tar.29.0405.8.

Cross JV, Easterbrook MA, Crook AM, Crook D, Fitzgerald JD, Innocenzi PJ, Jay CN, Solomon MG. 2001. Review: Natural enemies and biocontrol of pests of strawberry in Northern and Central Europe. Biocontrol Science and Technology. 11:165-216. doi: https://doi. org/10.1080/09583150120035639.

Evans GO. 1952. A new typhlodromid mite predaceous on Tetranychus bimaculatus Harvey in Indonesia. Annals and Magazine of Natural History 5:413-416. doi: https://doi. org/10.1080/00222935208654311.

Gerson U, Smiley RL, Ochoa R. 2003. Mites (Acari) for Pest Control. Oxford: Blackwell Science Ltd. doi: https://doi.org/10.1002/9780470750995. 
Gotoh T, Nozawa M, Yamaguchi K. 2004. Prey consumption and functional response of three acarophagous species to eggs of the two-spotted spider mite in laboratory. Applied Entomology and Zoology 39:97-105. doi: https://doi. org/10.1303/aez.2004.97.

Huffaker CB, Messenger PS, De Bach P. 1971. The natural enemy component in natural control and the theory of biological control. Di dalam: Huffaker CB (Eds.), Biological control. hlm. 16-62. New York: Plenum Press.

Hoy MA. 2011. Agricultural Acarology: Introduction to Integrated Mite Management. New York: CRC Press. doi: https://doi.org/10.1201/b10909.

Krips OE, Kleijn PW, Willems PEL, Gols GJZ, Dicke M. 1999. Leaf hairs influence searching efficiency and predation rate of the predatory mite Phytoseiulus persimilis Athias-Henriot (Acari: Phytoseiidae). Di dalam: Bruin J, Van der Greest LPS, Sabelis MW (Eds.), Proceedings of the 3rd Symposium of the European Association of Acarologists (Amsterdam, 1-5 Juli 1996). hlm. 389-398. London: Kluwer Academic Publishers.

Kongchuensin M, Charanasri V, Takafuji A. 2005. Geographic distribution of Neoseiulus longispinosus (Evans) and its habitat plants in Thailand. Journal of the Acarological Society of Japan 14:1-11. doi: https://doi.org/10.2300/ acari.14.1.

Meszaros A, Tixier MS, Cheval B, Barbar Z, Kreiter S. 2007. Cannibalism and intraguild predation in Typhlodromus exhilaratus and $T$. phialatus (Acari: Phytoseiidae) under laboratory conditions. Experimental and Applied Acarology 41:37-43. doi : 10.1007/s10493-006-9046-x.

Momen FM. 2010. Intra and interspecific predation by Neoseiulus barkeri and Typhlodromus negevi (Acari: Phytoseiidae) on different life stages: predation rates and effects on reproduction and juvenile development. Acarina 18:81-88.

McMurty JA, Rodriguez JG. 1987. Nutritional ecology of phytoseiidae mites. Di dalam: Slansky F JR, Rodriguez JG (Eds.), Nutritional Ecology of Insect, Mites, Spiders, and Related Invertebrates. hlm. 609-644. New York: Jhon Wiley and Sons.
Oliviera H, Janssen A, Pallini A, Venzon M, Fadini M, Duarte V. 2007. A phytoseiid predator from the tropics as potential biological control agents for the spider mite Tetranychus urticae Koch (Acari: Tetranychidae). Biological Control 42:105-109. doi: https://doi.org/10.1016/j. biocontrol.2007.04.011.

Puspitarini RD. 2005. Biologi dan Ekologi Tungau Merah Jeruk Panonychus citri (McGregor) (Acari: Tetranychidae). Disertasi. Bogor: Institut Pertanian Bogor.

Rachman MNY. 2011. Biologi dan Potensi Predasi Tungau Predator Neoseiulus longispinosus Evans (Acari: Phytoseiidae) pada Tungau Hama Tetranychus kanzawai Kishida (Acari: Tetranychidae). Tesis. Bogor: Institut Pertanian Bogor.

Rahman VJ, Babu A, Roobakumar A, Perumalsamy K. 2013. Functional and numerical responses of the predatory mite, Neoseiulus longispinosus, to the red spider mite, Oligonychus coffeae, infesting tea. Journal of Insect Science 12:1-12. doi: https://dx.doi.org/10.1673/031.012.12501.

Sabelis MW. 1985. Predation on spider mites. Di dalam: Helle W, Sabelis MW (Eds.), Spider Mites Their Biology, Natural Enemy and Control B. World Crop Pest IB. hlm.103-1279. Amsterdam: Elsevier.

Song ZW, Zheng Y, Zhang BX. Li DS. 2016. Prey consumption and functional response of Neoseiulus californicus and Neoseiulus longispinosus (Acari: Phytoseiidae) on Tetranychus urticae and Tetranychus kanzawai (Acari:Tetranychidae). Systematic \& Applied Acarology 21:936-946. https://doi.org/10.11158/ saa.21.7.7.

Zhang ZQ. 2003. Mites of Greenhouses: Identification, Biology and Control. Walingford: CABI Publishing. doi: https://doi. org/10.1079/9780851995908.0000.

Zhang YX, Zhang ZQ, Ji J, Lin JZ. 1999. Predation of Amblyseius longispinosus (Acari: Phytoseiidae) on Schizotetranychus nanjingensis (Acari: Tetranychidae), a spider mite injurious to bamboo in Fujian, China. Systematic \& Applied Acarology 4:63-68. doi: https://doi. org/10.11158/saa.4.1.9. 